Neuro/mages
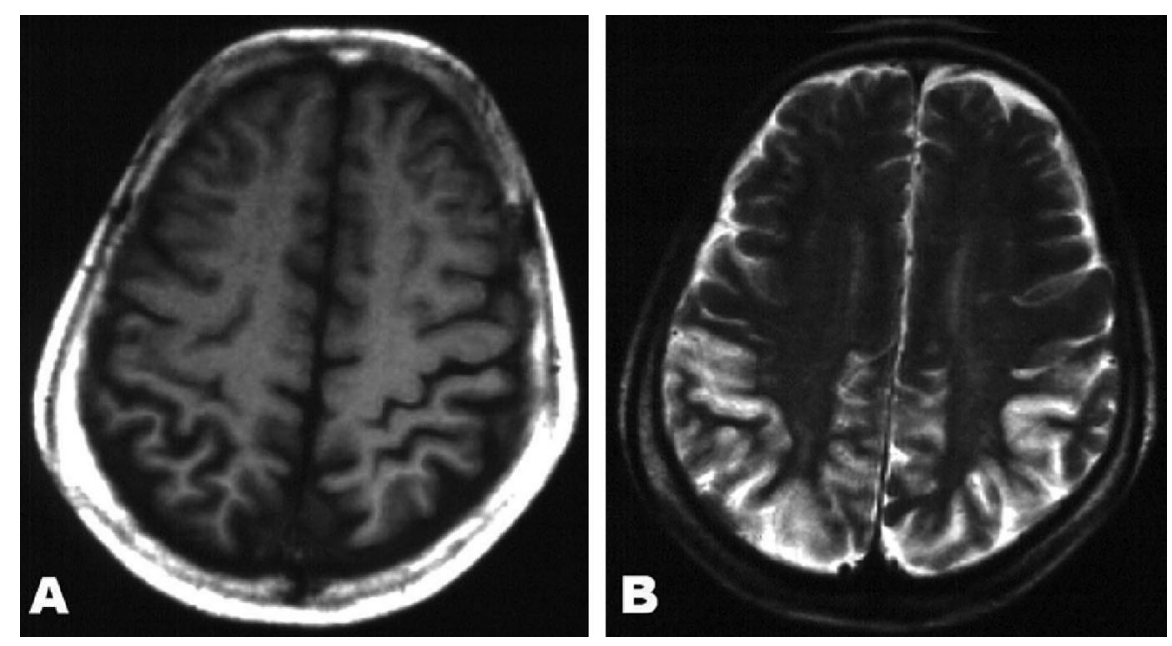

Figure. (A) Axial T1-weighted MRI of the brain showing symmetric parietooccipital atrophy without subcortical signal change, frontal atrophy, or hippocampal atrophy (not shown). (B) Diffusion-weighted MRI showing "ribbon-like" cortical hyperintensity, consistent with acute cortical injury commonly seen in the early stage of Creutzfeldt-Jakob disease.

\section{Creutzfeldt-Jakob disease manifesting as posterior cortical dementia}

H. Nodera, MD; A. Mori, MD; Y. Izumi, MD, PhD;

T. Sakamoto, $M D$; and R. Kaji, MD, PhD, Tokushima, Japan

A 70-year-old right-handed woman developed left hemineglect. Her memory, insight, and judgment were normal, but dressing apraxia, acalculia, and Balint syndrome were observed, consistent with posterior cortical dementia (PCD) ${ }^{1}{ }^{\mathrm{MRI}}$ demonstrated atrophy of the parieto-occipital cortices (figure, A), where cortical

Address correspondence and reprint requests to Dr. Hiroyuki Nodera, Department of Neurology, Tokushima University Hospital, 2-50-1 Kuramotocho Tokushima-City 770-8503 Japan; e-mail: hnodera@clin.med.tokushima-u.ac.jp hyperintensity by diffusion-weighted imaging (DWI) coexisted (see figure, B). ${ }^{2}$ The diagnosis of probable Creutzfeldt-Jakob disease (CJD) by World Health Organization criteria was made by the elevated 14-3-3 protein in CSF, subsequent akinetic mutism, and EEG changes. Since Alzheimer disease, CJD, and other neurodegenerative diseases may manifest as PCD, DWI of MRI and CSF 14-3-3 protein may help differentiate these etiologies and avoid risk of transmission from a patient with CJD.

1. Renner JA, Burns JM, Hou CE, McKeel DW, Storandt JM, Morris JC. Progressive posterior cortical dysfunction: a clinicopathologic series. Neurology 2004;63:1175-1180.

2. Shiga Y, Miyazawa K, Sato S, et al. Diffusion-weighted MRI abnormalities as an early diagnostic marker for Creutzfeldt-Jakob disease. Neurology 2004;63:443-449.

See also page 329 


\section{Neurology}

\section{Creutzfeldt-Jakob disease manifesting as posterior cortical dementia H. Nodera, A. Mori, Y. Izumi, et al. Neurology 2005;65;330 \\ DOI 10.1212/01.WNL.0000158698.35834.0D}

\section{This information is current as of July 25, 2005}

\section{Updated Information \& Services}

Supplementary Material

References

Subspecialty Collections

Permissions \& Licensing

Reprints including high resolution figures, can be found at: http://n.neurology.org/content/65/2/330.full

Supplementary material can be found at: http://n.neurology.org/content/suppl/2007/04/02/65.2.330.DC1

This article cites 2 articles, 2 of which you can access for free at: http://n.neurology.org/content/65/2/330.full\#ref-list-1

This article, along with others on similar topics, appears in the following collection(s):

\section{Prion}

http://n.neurology.org/cgi/collection/prion

Prion disease; see Infections/prion

http://n.neurology.org/cgi/collection/prion_disease

Visual processing

http://n.neurology.org/cgi/collection/visual_processing

Information about reproducing this article in parts (figures,tables) or in its entirety can be found online at:

http://www.neurology.org/about/about_the_journal\#permissions

Information about ordering reprints can be found online: http://n.neurology.org/subscribers/advertise

Neurology ${ }^{\circledR}$ is the official journal of the American Academy of Neurology. Published continuously since 1951, it is now a weekly with 48 issues per year. Copyright. All rights reserved. Print ISSN: 0028-3878. Online ISSN: 1526-632X.

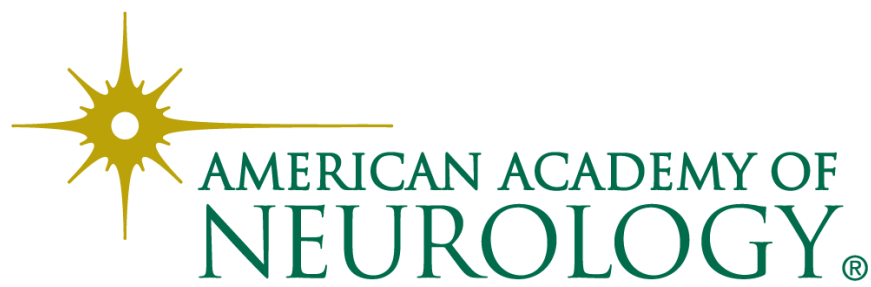

